\title{
KAJIAN GEOTEKNIK UNTUK OPTIMALISASI DESAIN TAMBANG BATUBARA MENGGUNAKAN LIMIT EQUILIBRIUM METHOD ${ }^{1)}$
}

\author{
Luqmanul Hakim Maulana ${ }^{2)}$ dan Jerry Dwi Fajar S.T., ${ }^{3)}$ \\ 2) Mahasiswa Teknik Pertambangan, Universitas Islam Bandung, \\ ${ }^{3)}$ PT BANTI INDONESIA, Balikpapan regency, Balikpapan, KALTIM.
}

\begin{abstract}
ABSTRAK
PT XYZ sebagai salah satu perusahaan yang bergerak dibidang pertambangan batubara yang terletak di Kabupaten Kutai Kartanegara, Provinsi Kalimantan Timur. Telah merencanakan pembuatan pit dan timbunan di suatu lahan yang belum dibuka. Oleh karena itu diperlukan studi geoteknik untuk menganalisa geometri lereng bukaan tambang serta timbunan yang telah direncanakan oleh pihak perusahaan.

Kegiatan penelitian dilakukan dengan mengumpulkan data primer yang diperoleh dari pengeboran geoteknik, pengukuran muka air tanah dari 9 titik yang dianggap mewakili karakteristik massa tanah atau batuan dari beberapa pit. Lapisan batuan penyusun lereng tambang didominasi oleh batupasir dan batulempung, dijumpai pula batu lanau, carbon disamping batubara yang akan ditambang. Tanah atau batuan di lokasi penelitian termasuk kriteria batuan sedang sampai lemah, dibuktikan oleh pendekatan indeks kekuatan geologi dan sifat mekanik batuan. Pengukuran muka air tanah di daerah penelitian termasuk dalam kondisi jenuh dengan kedalaman MAT 0,88 - 11,975 meter.

Penelitian dilakukan dengan jumlah pit sebanyak 7 pit, dan 13 penampang (section) yaitu penampang A-A' sampai dengan penampang N-N', yang merepresentasikan bentuk dari tiap pit penambangan batubara meliputi highwall dan lowwall. Kemantapan lereng untuk rencana desain tambang awal pada penampang A-A' sampai dengan penampang N-N' untuk lereng highwall dan lowwall faktor keamanannya terdapat yang sudah stabil namun masih dapat dioptimalkan, stabil dan tidak stabil, sehingga untuk lereng yang berada dalam kondisi stabil yang dapat dioptimalkan dilakukan desain ulang dengan kemiringan lereng yang curam dari sebelumnnya, kemudian untuk lereng yang tidak stabil dilakukan desain ulang dengan kemiringan lereng yang landai dari sebelumnnya. Rekomendasi lereng untuk penampang A-A' lereng highwall yaitu overall slope angle $33^{\circ}$ dan tinggi lereng $69,665 \mathrm{~m}$ serta untuk lereng lowwall yaitu overall slope angle $13^{\circ}$ dan tinggi lereng 48,105 m, penampang B-B' lereng highwall yaitu overall slope angle $29^{\circ}$ dan tinggi lereng 34,139 m serta untuk lereng lowwall yaitu overall slope angle $22^{\circ}$ dan tinggi lereng 40,109 m, penampang C-C' lereng highwall yaitu overall slope angle $30^{\circ}$ dan tinggi lereng $97,900 \mathrm{~m}$ serta untuk lereng lowwall yaitu overall slope angle $15^{\circ}$ dan tinggi lereng 69,284 m, penampang D-D' lereng highwall yaitu overall slope angle $49^{\circ}$ dan tinggi lereng 77,023 m serta untuk lereng lowwall yaitu overall slope angle $7^{0}$ dan tinggi lereng $132,16 \mathrm{~m}$.
\end{abstract}

Kata Kunci: Kestabilan Lereng, Highwall, Lowwall, Sidewall, Metode Kesetimbangan Batas

\begin{abstract}
PT XYZ as one of the companies engaged in coal mining located in Kutai Kartanegara Regency, East Kalimantan Province. Planned construction of pits and waste dump on land that has not been cleared. Therefore a geotechnical study is needed to analyze the geometry of the mine opening slope and the pile planned by the company.

Research activities carried out by collecting primary data obtained from geotechnical drilling, groundwater level measurements from 9 points that are considered to represent the characteristics of the soil mass or rock from several pits. Rock layers making up the mine slope are dominated by sandstone and claystone, silt stone, carbon in addition to the coal to be mined. The soil or rocks at
\end{abstract}


the study site are of moderate to weak rock criteria, evidenced by the geological strength index approach and rock mechanical properties. Based on ground water level measurements in the study area included in saturated conditions with a MAT depth of 0.88 - 11.975 meters from the surface.

The study was conducted with a total of 7 pits, and 13 section sections, namely A-A section to $N-N$ section, which represent the shape of each coal mining pit including highwall and lowwall. Slope stability for the initial mine design plan on cross sections A-A 'to $N$-N cross sections for highwall and lowwall slopes there are safety factors that are already stable but can still be optimized, stable and unstable, so for slopes that are in stable conditions that are can be optimized redesigned with a steep slope from the previous, then for unstable slopes redesigned with a safety slope from the previous. Recommended slopes for cross section A-A 'highwall slopes are overall slope angle 330 and slope height 69,665 $\mathrm{m}$ and for lowwall slopes are overall slope angle 130 and slope height 48,105 m, cross section B-B' highwall slopes are overall slope angle 290 and slope height 34,139 $m$ and for lowwall slopes namely overall slope angle 220 and slope height 40,109 m, cross section $C$-C 'highwall slope is overall slope angle 300 and slope height 97,900 $\mathrm{m}$ and for lowwall slopes are overall slope angle 150 and slope height 69,284 m, cross section D-D 'highwall slope is 490 overall slope angle and $77.023 \mathrm{~m}$ slope height and lowwall slope angle 70 overall and $132.16 \mathrm{~m}$ slope height.

Key Word: Slope Stability, Highwall, Lowwall, Sidewall, Limit Equilibrium Method

\section{A. PENDAhuluan}

Aktivitas penambangan pada umumnya melakukan kegiatan penggalian serta penimbunan material yang berkaitan dengan lereng baik itu berupa lereng kerja (working slope) maupun lereng akhir (final slope). Lereng-lereng tersebut harus dianalisis kemantapannya untuk mencegah bahaya kelongsoran yang dapat terjadi sewaktu-waktu, karena berhubungan dengan keselamatan pekerja dan keamanan peralatan. Pada kegiatan penambangan, seperti penggalian pada suatu lereng akan menyebabkan terjadinya perubahan besarnya gaya yang bekerja pada lereng tersebut yang mengakibatkan terganggunya kestabilan lereng.

Melakukan optimalisasi geometri lereng desain pit guna mendukung rencana penambangan batubara dan memaksimalkan cadangan batubara yang bisa ditambang. Kemiringan dan tinggi suatu lereng sangat mempengaruhi stabilitas lereng, semakin besar kemiringan dan tinggi suatu lereng, maka stabilitas lerengnya semakin kecil. Berdasarkan keterdapatan pergerakan tanah di salah satu pit menjadi salah satu hal perlu dilakukan evaluasi serta kajian kembali desain lereng tambang yang telah di buat. Selain itu ada rencana pembuatan pit dan timbunan di suatu lahan yang belum dibuka. Oleh karena itu untuk menjaga kestabilan lereng yang aman maka diperlukan kajian geoteknik untuk mengoptimalisasi geometri lereng bukaan tambang serta timbunan yang telah direncanakan oleh pihak perusahaan.

Tanah atau batuan di lokasi penelitian termasuk kriteria batuan sedang sampai lemah, dibuktikan oleh pendekatan indeks kekuatan geologi dan sifat mekanik batuan dengan nilai UCS 0,18 mpa sampai 13,09 mpa sehingga kemungkinan jenis longsoran yang terjadi adalah longsoran busur. Umumnya kondisi seperti itu dilakukan analisis menggunakan metode kesetimbangan batas atau (limit equilibrium method) yang mempertimbangkan kesetimbangan gaya dalam arah vertical dan kesetimbangan momen pada pusat lingkaran bidang glincir. Metode ini digunakan pada longsoran busur dengan material penyusun lereng memiliki karakteristik yang tidak homogen sepanjang lereng dan longsoran busur tidak melewati kaki lereng dan. Dalam metode ini gaya geser antar bidang diasumsikan nol. Memastikan bahwa tegangan normal efektif pada dasar setiap bidang irisan selalu positif, pengaruh tegangan perlu diperhitungkan dalam analisis. 
Tujuan dari kajian geoteknik ini adalah untuk melakukan analisis kemantapan lereng guna mendukung rencana penambangan batubara pada pit $1,4,7,8,9,10$, dan 11 , kemudian mengkaji lereng tunggal serta mengkaji kemantapan lereng timbunan.

\section{B. METODOLOGI PENELITIAN}

Metode penelitian yang digunakan dibagi menjadi beberapa tahapan yaitu tahap persiapan, pengambilan data dan pengolahan data.

\section{B.1 Tahap Persiapan}

Tahap persipan ini penulis melakukan studi literatur mencari bahan pustaka yang menunjang, diperoleh dari badan dinas terkait, laporan perusahaan, laporan penelitian terdahulu dan buku-buku penunjang mengenai kajian kemantapan lereng pada tambang batubara sistem terbuka.

\section{B.2 Pengambilan Data}

Penyelidikan ini dilakukan untuk mendapatkan faktor internal dan faktor eksternal yang mempengaruhi pemodelan dan analisis geoteknik. Kegiatan utama dalam penyeledikan geoteknik untuk mendukung desain tambang terbuka adalah "Pengeboran Geoteknik". Hal ini dilakukan pada area yang belum tersingkap maupun yang sudah tersingkap atau terbuka, seiring dengan akan dibuka penggalian penambangan, pengeboran geoteknik permukaan bertujuan untuk mendapatkan data informasi tambahan tentang kondisi massa batuan di lapangan sehingga diketahui input parameter kekuatan batuan yang nanti akan digunakan ketika pemodelan dan analisis geoteknik.

Pengambilan data primer dilakukan dengan observasi lapangan melakukan pengeboran geoteknik yang bertujuan untuk mendapatkan informasi batuan penyusun lereng tambang baik berupa sample core, kemudian perekaman informasi logbor yang mewakili data lokasi penelitian hasil dari tim geologis serta tim geoteknik, mengukur kedalaman muka air tanah, kemudian dari sample core hasil pengeboran dilakukan uji laboratorium untuk mengetahui data sifat fisik dan sifat mekanik batuan yang mewakili kondisi batuan di lokasi penyeledikan.

Pengambilan data sekunder diantaranya data yang diperoleh dari kegiatan eksplorasi seperti peta topografi serta model geologi bawah permukaan di lokasi penelitian, kemudian mengetahui data rencana design akhir rencana penambangan batubara, mengetahui data getaran gempa dari peta zonasi gempa yang dikeluarkan oleh kementrian pekerjaan umum, serta data getearan peledakanyanf pernah dilakukan dari tim teknis.

\section{B.3. Pengolahan Data}

\section{B.3.1 Pemodelan Lereng}

Pemodelan lereng adalah representasi alamiah lereng bukaan tambang (Gambar 1.) yang akan dianalisis dengan memasukkan faktor internal dan faktor eksternal, sehingga dapat menggambarkan dan mewakili keadaan lereng bukaan tambang mendekati keadaan sebenarnya di lapangan. Dalam studi geoteknik ini, pemodelan dan analisis kemantapan lereng akan menggunakan pemodelan numerik metode kesetimbangan batas.

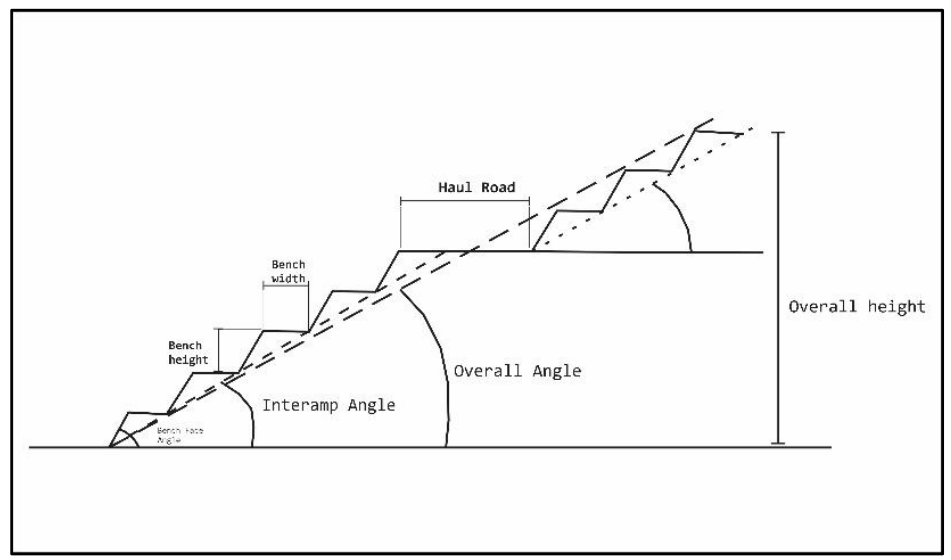


Gambar 1. Geometri lereng pada tambang terbuka (Hoek dan Bray, 1981)

Analisis kemantapan lereng bertujuan untuk mengetahui kondisi stabilitas lereng bukaan tambang yang akan terbentuk sesuai dengan rencana penambangan (pit plan) yang dibuat dapat dilihat pada Gambar 2.

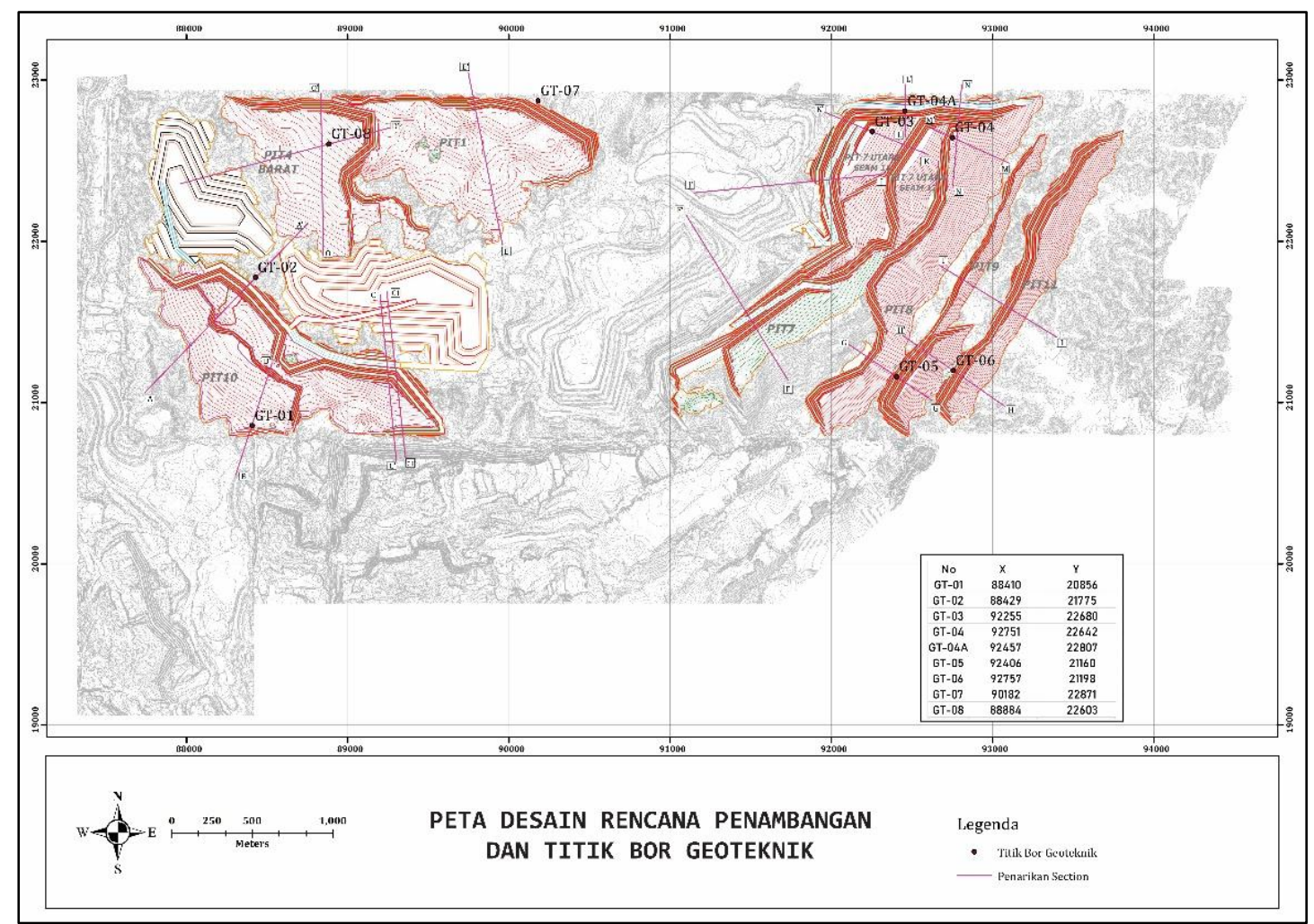

Gambar 2. Desain Rencana Penambangan

\section{B.3.2 Hasil Uji Laboratorium}

Sampel (Undisturbed Sample)yang telah diambil dari pengeboran geoteknik yang dilakukan di 9 titik berbeda yang tersebar di 7 pit akan dilakukan pengujian sampel di Laboratorium Geomekanika untuk mengetahui nilai sifat fisik (berat natural, berat jenuh, porositas dan void ratio) dan sifat mekanik (kuat tekan, kuat tarik dan point load) dari batuan penyusun pada lereng tambang yang akan dibuka. Berikut adalah contoh tabel hasil pengujian sampel di Laboratorium Geomekanika (Tabel 1.) 
Tabel 1. Contoh Hasil uji laboratorium sampel titik bor GT-06

\begin{tabular}{|c|c|c|c|c|c|c|c|c|}
\hline \multicolumn{4}{|c|}{ Sample ID/Hole No } & GT06/01 & GT06/03 & GT06/04 & GT06/05 & GT06/06 \\
\hline \multirow[t]{2}{*}{ No } & \multicolumn{2}{|c|}{$\operatorname{Depth}(m)$} & Unit & $01,70-02,70$ & $11,50-15,00$ & $15,60-16,50$ & $22,00-23,30$ & $28,80-29,80$ \\
\hline & \multicolumn{2}{|c|}{ Sample Type } & & Carbon & Sandstone & Sandstone & Sandstone & Claystone \\
\hline 1 & \multicolumn{2}{|c|}{ Natural Water Content } & $\%$ & 21,3 & 20,8 & 19,46 & 18,17 & 15,97 \\
\hline 2 & \multicolumn{2}{|c|}{ Spesific Gravity } & & 2,69 & 2,66 & 2,67 & 2,68 & 2,66 \\
\hline 3 & \multicolumn{2}{|c|}{ Unit Weight Natural State } & $\mathrm{gr} / \mathrm{cm}^{3}$ & 1,72 & 1,99 & 2,07 & 2,07 & 2,14 \\
\hline 4 & \multicolumn{2}{|c|}{ Dry Unit Weight } & $\mathrm{gr} / \mathrm{cm}^{3}$ & 1,42 & 1,65 & 1,73 & 1,75 & 1,85 \\
\hline 5 & \multicolumn{2}{|l|}{ Degree Saturation } & $\%$ & 63,52 & 90,4 & 96,15 & 92,21 & 96,16 \\
\hline 6 & \multicolumn{2}{|l|}{ Natural Porosity } & $\%$ & 47,46 & 37,98 & 35,09 & 34,53 & 30,67 \\
\hline 7 & \multicolumn{2}{|c|}{ Natural Void Ratio } & & 0,9 & 0,61 & 0,54 & 0,53 & 0,44 \\
\hline \multirow{2}{*}{10} & \multirow{2}{*}{ Triaxial UU } & Int, Fric Angle & degree & 8,19 & 24,56 & 31,68 & 31,96 & 18,09 \\
\hline & & Cohesion & $\mathrm{kPa}$ & 58,68 & 166,51 & 86,51 & 339,78 & 374,99 \\
\hline \multirow{3}{*}{11} & \multirow{3}{*}{ UCS } & Ultimate Strength & Mpa & 0,06 & 0,37 & 0,96 & 1,21 & 0,76 \\
\hline & & Poisson's Ratio & & 0,13 & 0,31 & 0,34 & 0,26 & 0,4 \\
\hline & & Modulus Elastisity & $\mathrm{MPa}$ & 1,3 & 13,5 & 34,3 & 58.00 & 30,3 \\
\hline 12 & $\begin{array}{l}\text { Tensile Strength } \\
\text { (Brazillian Test) }\end{array}$ & $\sigma \mathrm{t}$ & $\mathrm{kg} / \mathrm{cm}^{2}$ & 6,05 & 6,88 & 7,89 & 7,84 & 7,67 \\
\hline \multirow{2}{*}{13} & \multirow{2}{*}{ Ultrasonic } & $\mathrm{E}$ & $\mathrm{kg} / \mathrm{cm}^{2}$ & 1362,44 & 4786,6 & 7759,07 & 11910,02 & 11033,03 \\
\hline & & $\mu$ & & 0,46 & 0,58 & 0,47 & 0,47 & 0,45 \\
\hline
\end{tabular}

\section{B.3.3 Input Parameter Yang Digunakan Untuk Pemodelan Geoteknik Pit Tambang}

Dalam kajian ini, pemodelan dan analysis kemantapan lereng High-wall, Side-wall serta Low-wall berdasarkan desain rencana akhir tambang, Analisis lereng ini akan menggunakan pendekatan analisis sebagai berikut :

- Beban dinamik

Beban dinamik yang dimaksudkan dalam pemodelan ini gaya luar berupa faktor kegempaan dengan satuan g (gravity) yang didasarkan pada Peta Zonasi Gempa Indonesia. Untuk lokasi penelitian memiliki beban dinamik sebesar 0,093 g mengambil nilai maksimum dari faktor gempa. Untuk pemodelan geometri lereng tambang dan lereng timbunan yang digunakan pada penelitian ini berdasarkan percepatan getaran peledakan yang dihasilkan oleh perusahaan yaitu $0,15 \mathrm{~g}$.

- $\quad$ Karakteristik material

Input parameter pemodelan geoteknik (sifat fisik dan sifat mekanik) batuan untuk semua lapisan pembentuk model lereng ditentukan berdasarkan karakterisasi massa batuan hasil dari uji laboratorium. Database salah satu dari beberapa hasil uji laboratorium geomekanik yang dilakukan dengan beberapa penyesuian dapat dilihat pada Tabel 2 :

Tabel 2. Input parameter penampang pemodelan geoteknik pit 10

\begin{tabular}{ccccr}
\hline No & Lithology & $\begin{array}{c}\text { Unit Weight } \\
\left(\mathrm{kN} / \mathrm{m}^{3}\right)\end{array}$ & $\begin{array}{c}\text { Int. Fric Angle } \\
\left({ }^{\circ}\right)\end{array}$ & $\begin{array}{c}\text { Cohesion } \\
(\mathrm{kPa})\end{array}$ \\
\hline 1 & Claystone & 20.20 & 18.56 & 79.12 \\
2 & Claystone & 19.50 & 35.15 & 400.00 \\
3 & Carbon & 17.80 & 15.96 & 142.75 \\
4 & Sandstone & 22.87 & 35.79 & 10.00 \\
4 & Soil & 20.30 & 15.96 & 55.27 \\
5 & Claystone & 19.20 & 19.27 & 92.47 \\
6 & Sandstone & 22.90 & 35.79 & 375.66 \\
7 & Sandstone & 21.43 & 41.91 & 388.13 \\
8 & Sandstone & 21.06 & 43.23 & 378.55 \\
9 & Claystone & 21.35 & 37.32 & 314.28 \\
10 & Waste Dump & 16.90 & 19.20 & 50.00 \\
11 & Coal & 12.60 & 34.13 & 120.00 \\
\hline
\end{tabular}

- Muka air tanah

Untuk mengetahui pengaruh air, dalam model direpresentasikan dengan garis muka air tanah. Efek dari keberadaan air dalam massa batuan adalah menambah massa jenis batuan sehingga beban yang harus ditahan oleh lereng bertambah. Di sisi lain juga air menyebabkan menurunnya kekuatan massa batuan karena menimbulkan tekanan pori. Dari 
hasil pengukuran ketinggian MAT yang hampir mendekati permukaan maka diasumsikan bentuk muka air tanah berdasarkan gambar kondisi air oleh Hoek \& Bray (Gambar 3) Dalam pemodelan lereng ini menggunakan asumsi muka air tanah sesuai kondisi MAT nomor 5 atau keadaan jenuh.

\section{B.3.4 Input Parameter Yang Digunakan Untuk Pemodelan Geoteknik Timbunan}

Parameter geoteknik material timbunan ditentukan dengan cara pendekatan, yaitu dengan memperkirakan suatu parameter eqivalen yang mewakili campuran material tersebut, yang didasarkan atas data bor. Densitas rata-rata batulempung dan batupasir berturut-turut adalah; 2,14 dan $2,17 \mathrm{gr} / \mathrm{cm}^{3}$. Densitas material in-situ eqivalen $=(55 \% \mathrm{x}(2,14)+45 \% \mathrm{x}(2,17))=2,153 \mathrm{gr} / \mathrm{cm}^{3}$.

Density material in-situ eqivalen $=2,153 \mathrm{gr} / \mathrm{cm}^{3}$. Swell Factor material campuran diperkirakan (umumnya) $\sim 80 \%$. Sehingga, density material timbunan (lepas) $=2,153 \mathrm{gr} / \mathrm{cm}^{3} \times 80 \%=1,723$ $\mathrm{gr} / \mathrm{cm}^{3}$. Jadi, bobot isi (unit weight) tanah timbunan eqivalen $=1723 \mathrm{~kg} / \mathrm{m}^{3} \times 9,81 \mathrm{~m} / \mathrm{dt}^{2}=16.902$ $\mathrm{N} / \mathrm{m}^{3}=16,902 \mathrm{kN} / \mathrm{m}^{3}$.

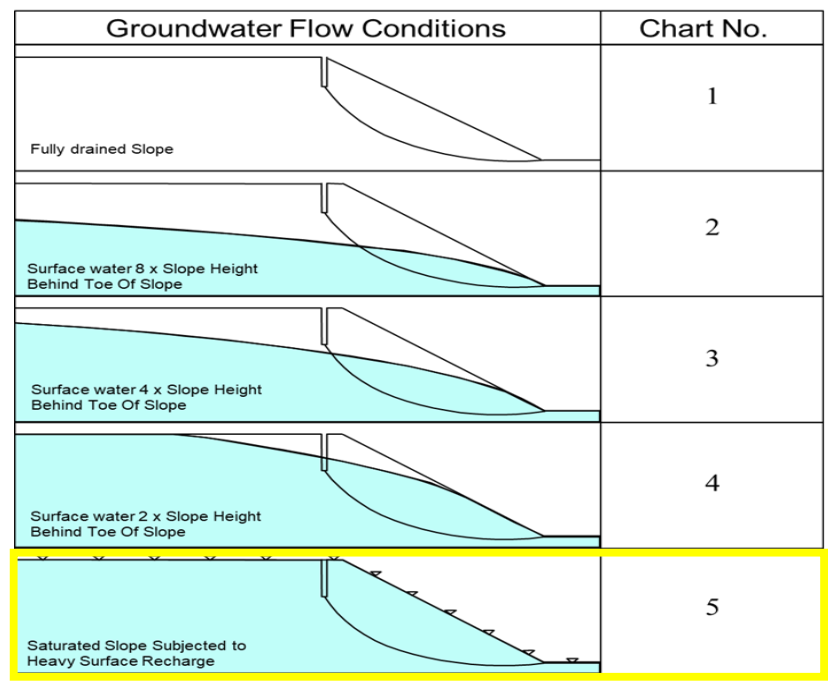

Gambar 3. Kondisi muka air tanah yang digunakan (E. Hoek \& J. W. Bray, 1981)

Parameter kekuatan material timbunan eqivalen terdiri dari kohesi (c) dan sudut gesek-dalam $(\phi)$, ditentukan dengan menggunakan kurva, sebagai berikut:

- Kurva hubungan densitas dan sudut gesek-dalam material waste (untuk timbunan yang dominan bersifat pasiran), atau

- Kurva hubungan antara IP (index plasticity) dan sudut gesek-dalam material waste (untuk timbunan yang dominan lempungan). 


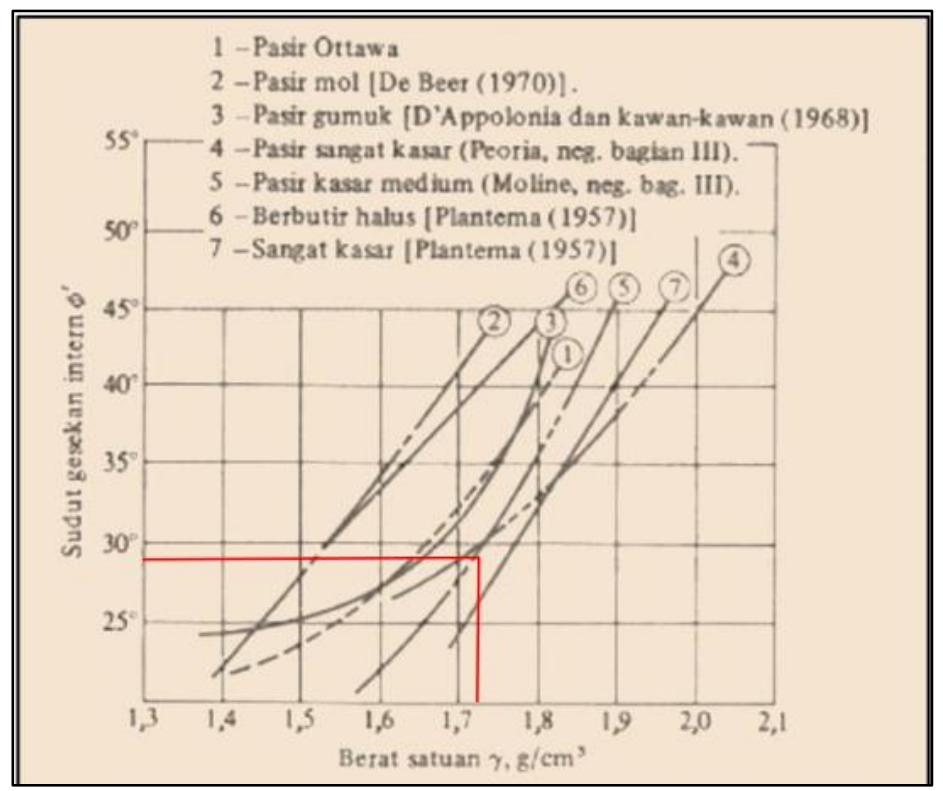

Gambar 4. Kurva hubungan sudut gesek dalam dengan densitas material timbunan

Dari kurva pada Gambar 4.6 dapat ditentukan sudut gesek dalam material timbunan eqivalen, $\varnothing$ waste $=28^{\circ}$. Dari kurva pada Gambar 4.7, dapat ditentukan sudut gesek dalam material timbunan eqivalen (umumnya $\sim$ IP (material clay) $=15 \%-25 \%$, diambil $=20 \%$ ), adalah $\varnothing$ waste $=12^{\circ}$.

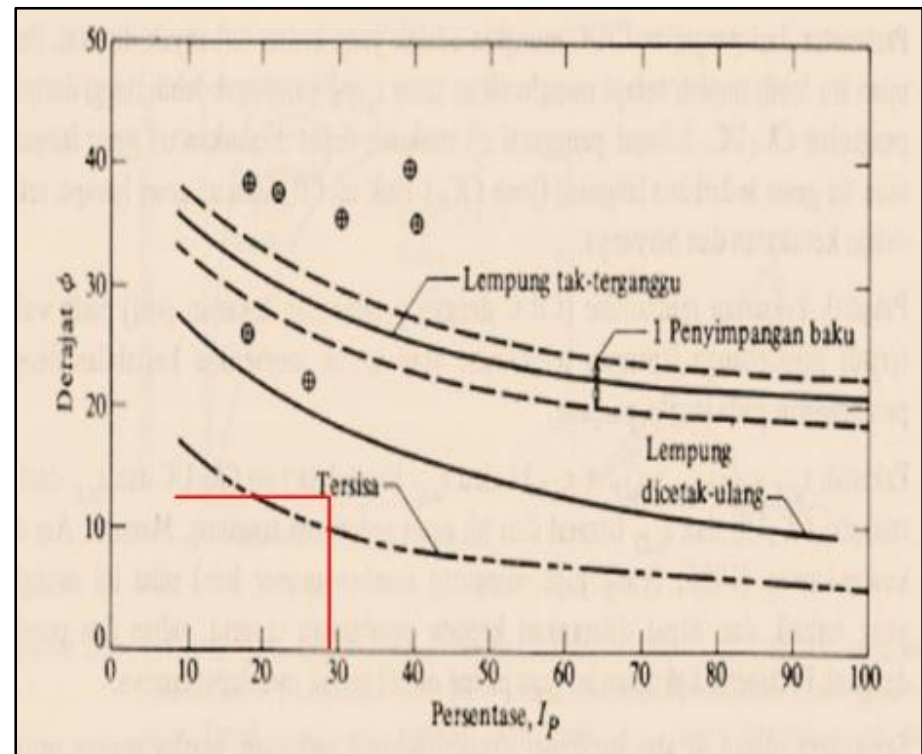

Gambar 5. Kurva hubungan sudut gesek dengan IP material timbunan

Sehingga sudut gesek dalam material timbunan ekivalen $=(12)(55 \%)+(28)(45 \%)=19,2$ derajat. Dengan demikian, parameter geoteknik material timbunan untuk desain ditentukan sebagai berikut

- Bobot isi (unit weight) $=16,902 \mathrm{kN} / \mathrm{m}^{3}$

- Kohesi (cohesion) $\quad=50 \mathrm{kPa}$

- Sudut gesek-dalam $\quad=19,2^{\circ}$ 


\section{B.3.5 Kriteria Kemantapan}

Analisis ini akan menggunakan $\mathrm{FK} \geq 1,1$ untuk menyatakan bahwa lereng dalam keadaan stabil dengan nilai probabilitas kelongsoran maksimal 5\%, sesuai kriteria faktor keamanaan yang dianjurkan KepMen ESDM nomor 1827, 2018. Jika hasil simulasi mempunyai FK $<1,1$ dan nilai probabilitas kelongsoran $>5 \%$, maka lereng dinyatakan belum stabil.

Tabel 3.Kriteria faktor keamanan (Kepmen ESDM 1827 : 2018)

\begin{tabular}{|c|c|c|c|c|}
\hline \multirow[b]{2}{*}{ Jenis Lereng } & \multirow[b]{2}{*}{$\begin{array}{c}\text { Keparahan } \\
\text { Longsor } \\
\text { (Consequences } \\
\text { of Failure/CoF) }\end{array}$} & \multicolumn{3}{|c|}{$\begin{array}{c}\text { Kriteria dapat diterima (Acceptance } \\
\text { Criteria) }\end{array}$} \\
\hline & & $\begin{array}{c}\text { Faktor } \\
\text { Keamanan } \\
\text { (FK) Statis } \\
\text { (Min) }\end{array}$ & $\begin{array}{c}\text { Faktor } \\
\text { Keamanan } \\
\text { (FK) } \\
\text { Dinamis } \\
\text { (Min) }\end{array}$ & $\begin{array}{c}\text { Probabilitas } \\
\text { Longsor } \\
\text { (Probability of } \\
\text { Failure) } \\
\text { (maks) PoF } \\
\text { (FK } \leq 1)\end{array}$ \\
\hline \multirow[t]{2}{*}{$\begin{array}{l}\text { Lereng } \\
\text { Tunggal }\end{array}$} & $\begin{array}{l}\text { Rendah s.d. } \\
\text { Tinggi }\end{array}$ & 1,1 & Tidak Ada & $25-50 \%$ \\
\hline & Rendah & $1,14-1,2$ & 1,0 & $25 \%$ \\
\hline \multirow[t]{3}{*}{ Inter-ramp } & Menengah & $1,2-1,3$ & 1,0 & $20 \%$ \\
\hline & Tinggi & $1,2-1,3$ & 1,1 & $10 \%$ \\
\hline & Rendah & $1,2-1,3$ & 1,0 & $15-20 \%$ \\
\hline \multirow[t]{2}{*}{$\begin{array}{l}\text { Lereng } \\
\text { Keseluruhan }\end{array}$} & Menengah & 1,3 & 1,05 & $10 \%$ \\
\hline & Tinggi & $1,3-1,5$ & 1,1 & $5 \%$ \\
\hline
\end{tabular}

\section{HASIL DAN PEMBAHASAN}

\section{C.1 Pemodelan dan Analisis Kemantapan Lereng Tunggal}

Analisis kestabilan untuk lereng tunggal (single slope) dilakukan untuk menentukan tinggi dan sudut lereng tunggal, dengan cara memvariasikan tinggi dan kemiringan lereng sampai diperoleh geometri lereng yang stabil dan aman. Hasil simulasi lereng tunggal menggunakan variasi sudut dan ketinggian yang berbeda-beda untuk menunjukan bahwa semua model yang disimulasikan diharapkan dapat digunakan dalam kondisi yang stabil. adapun contoh dari beberapa hasil simulasi lereng dapat dilihat pada (Gambar 6. dan Tabel 4.)

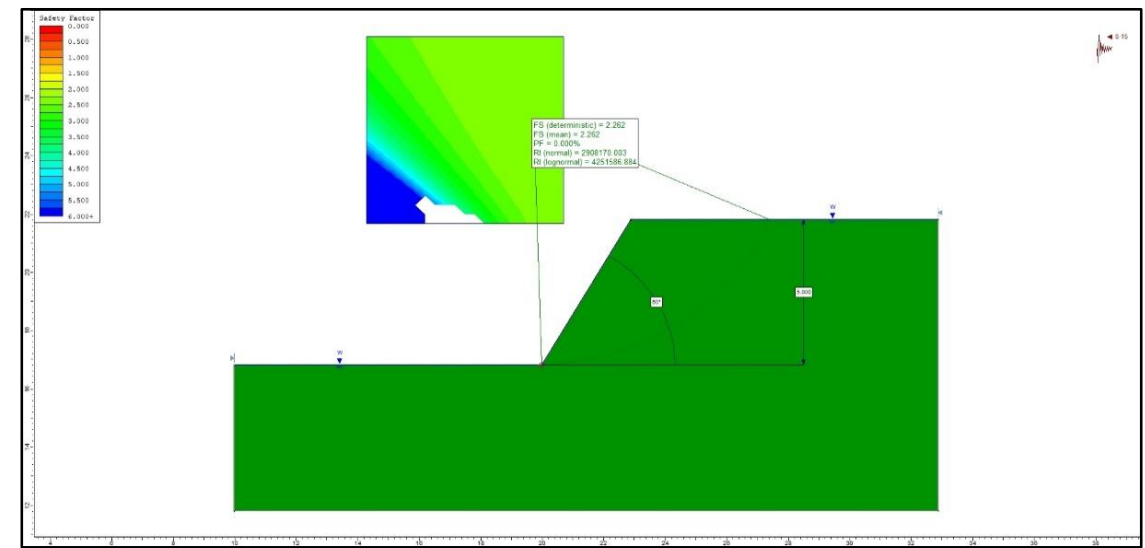

Gambar 6. Contoh simulasi lereng tunggal litologi claystone

$$
\left(\mathrm{H}=5 \mathrm{~m}, \alpha=60^{\circ}, \mathrm{SF}=2,26, \mathrm{PF}=0 \%\right)
$$


Tabel 4. Rekapitulasi hasil simulasi lereng tunggal

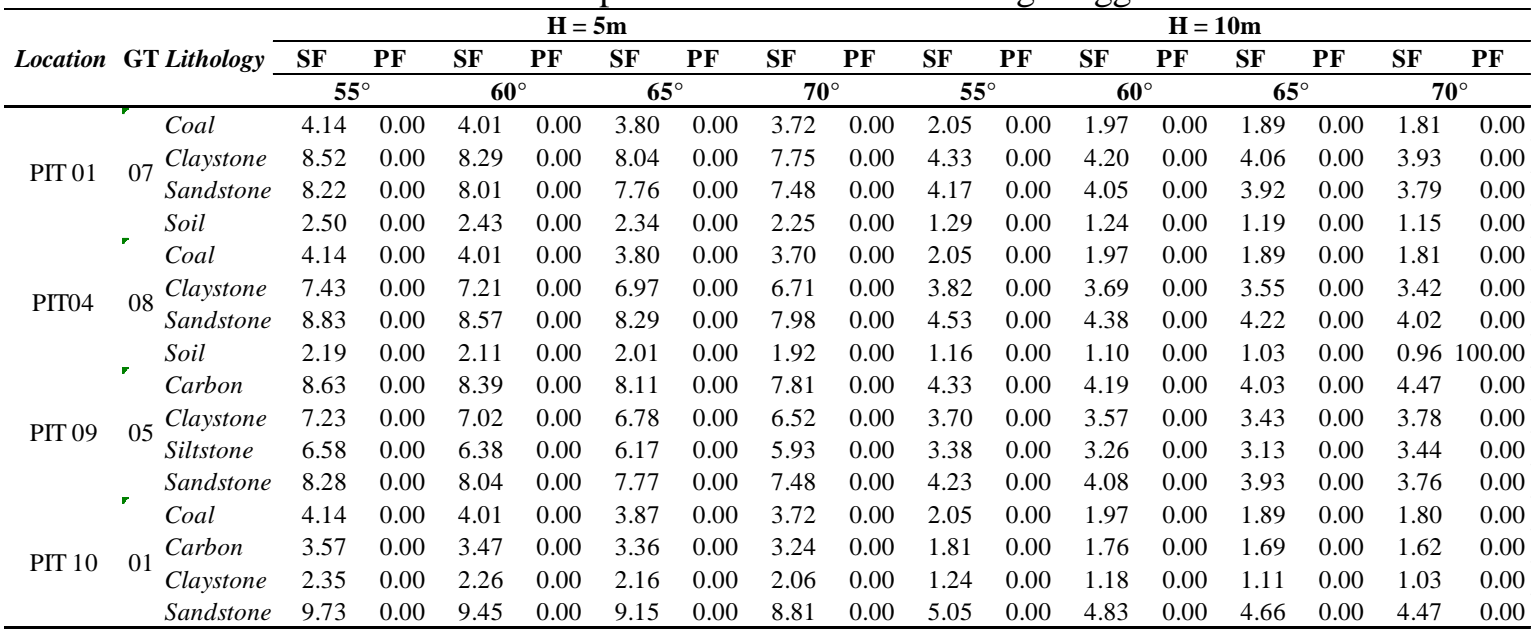

\section{C.2 Pemodelan dan Analisis Kemantapan Lereng Pit}

Analisis kemantapan lereng keseluruhan bertujuan untuk menentukan tingkat faktor kemanan dan probabilitas kelongsoran suatu lereng dengan membuat model lereng pada sudut dan tinggi tertentu. Hasil dari analisis yang dilakukan pada 7 pit tersebut adalah rekomendasi tinggi dengan sudut lereng tertentu yang diijinkan berdasarkan (Kepmen. 1827) atau (Stacey, 2009). Adapun beberapa pemodelan yang telah dilakukan sebagai berikut :

- Penampang B-B' untuk pit 10 (highwall)

Hasil pemodelan lereng highwall pada penampang B-B' menunjukan rencana geometri lereng bukaan akhir tambang dengan tinggi lereng 35,892 meter dan sudut kemiringan lereng $39^{\circ}$ menunjukan desain lereng yang tidak aman, sehingga agar lereng menjadi aman maka lereng dilakukan desain ulang geometri lereng dengan menurunkan sudut kemiringan $39^{\circ}$ menjadi $31^{\circ}$, sehingga nilai $\mathrm{FK}=0,844$ dan $\mathrm{PK}=100 \%$ menjadi $\mathrm{FK}=1,131$ dan $\mathrm{PK}=$ 0\% (Gambar 7 dan Gambar 8).

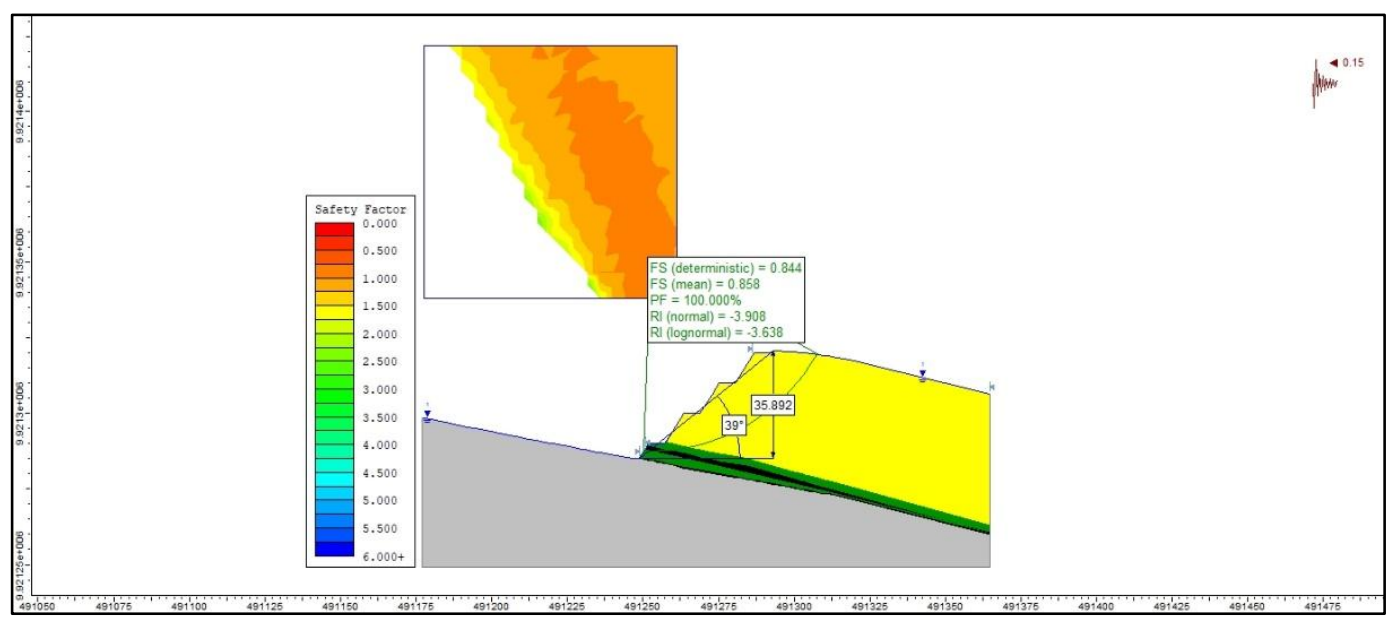

Gambar 7. Simulasi highwall penampang B-B' (desain awal)

$$
\left(\mathrm{H}=35,892 \mathrm{~m}, \alpha=39^{\circ}, \mathrm{FK}=0,844, \mathrm{PK}=100 \%\right)
$$




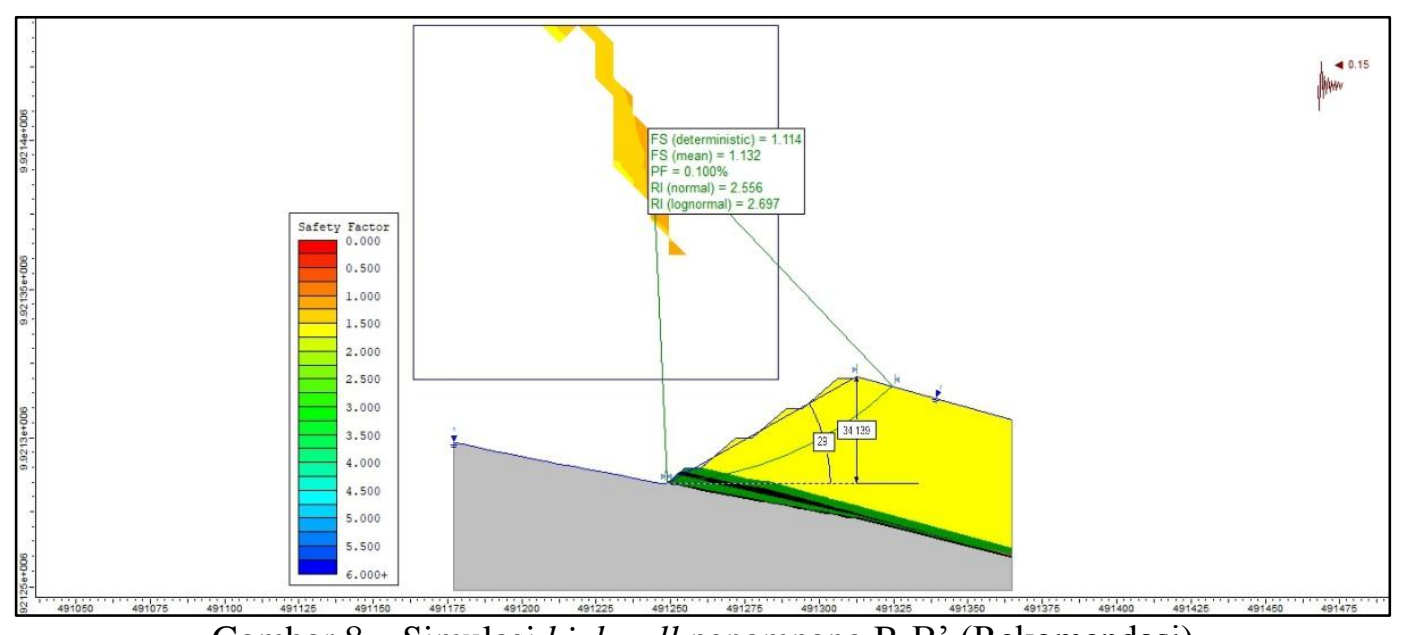

Gambar 8. Simulasi highwall penampang B-B' (Rekomendasi)

$$
\left(\mathrm{H}=35,892 \mathrm{~m}, \alpha=29^{\circ}, \mathrm{FK}=1,114, \mathrm{PK}=0,1 \%\right)
$$

- Penampang B-B' untuk pit 10 (lowwall)

Hasil pemodelan lereng lowwall pada penampang B-B' menunjukan rencana geometri lereng bukaan akhir tambang dengan tinggi lereng 37,321 meter dan sudut kemiringan lereng $27^{\circ}$ menunjukan desain lereng yang kritis, sehingga agar lereng menjadi aman maka lereng dilakukan desain ulang geometri lereng dengan menurunkan sudut kemiringan $27^{\circ}$ menjadi $22^{\circ}$, sehingga nilai $\mathrm{FK}=1,064$ dan $\mathrm{PK}=0 \%$ menjadi $\mathrm{FK}=1,132$ dan $\mathrm{PK}=0 \%$ (Gambar 9 dan Gambar 10).

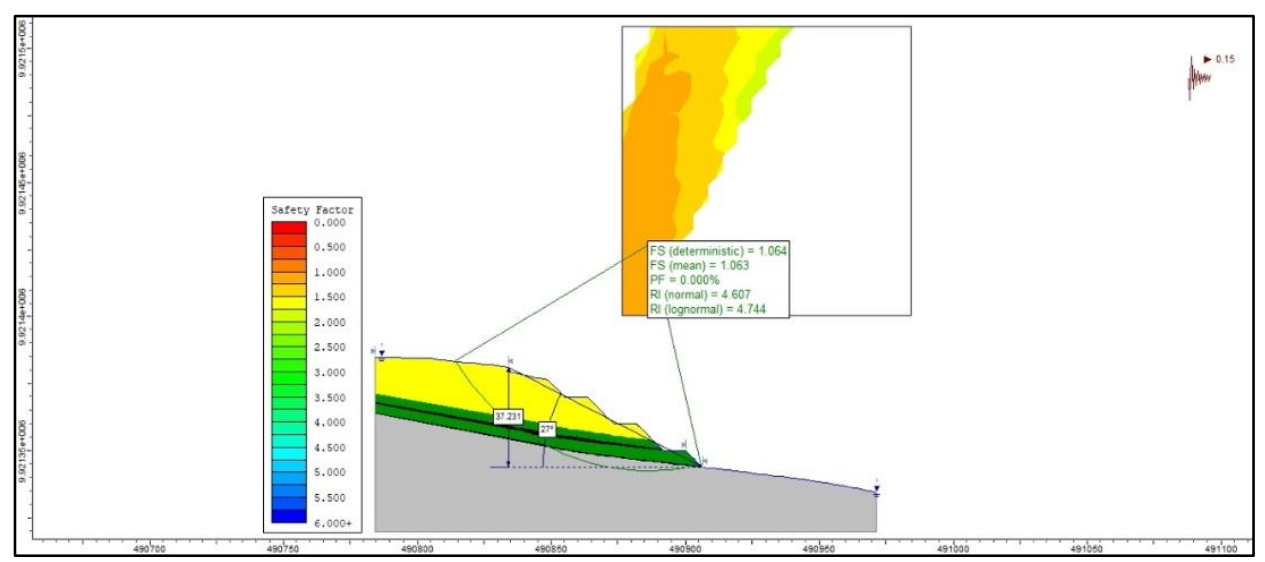

Gambar 9. Simulasi lowwall penampang B-B' (desain awal) $\left(\mathrm{H}=37,231 \mathrm{~m}, \alpha=27^{0}, \mathrm{FK}=1,064, \mathrm{PK}=0 \%\right)$

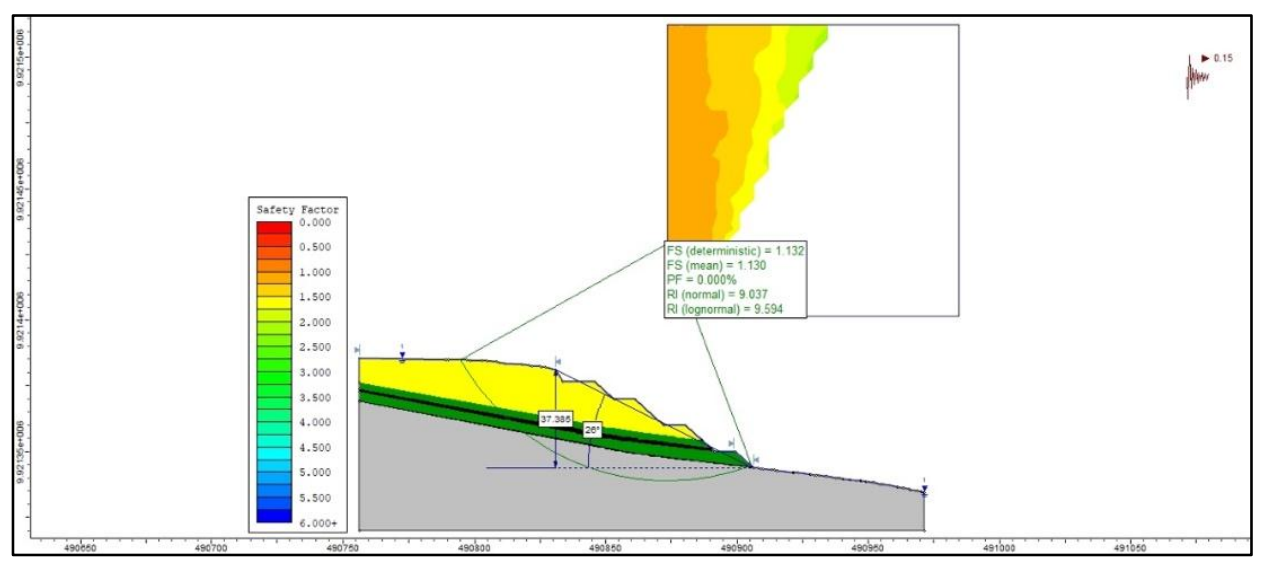


Gambar 10. Simulasi lowwall penampang B-B' (Rekomendasi) $\left(\mathrm{H}=37,385 \mathrm{~m}, \alpha=26^{\circ}, \mathrm{FK}=1,132, \mathrm{PK}=0 \%\right)$

- Penampang O-O' untuk pit 4 (sidewall)

Hasil pemodelan lereng sidewall pada penampang O-O' menunjukan rencana geometri lereng bukaan akhir tambang dengan tinggi lereng 63,869 meter dan sudut kemiringan lereng $40^{\circ}$ menunjukan desain lereng yang aman, sehingga agar lereng lebih optimal tidak banyak mengeruk overburden maka dilakukan desain ulang geometri lereng dengan menaikan sudut kemiringan $40^{\circ}$ menjadi $51^{\circ}$, sehingga nilai $\mathrm{FK}=1,273$ dan $\mathrm{PK}=0 \%$ menjadi $\mathrm{FK}=1,136$ dan $\mathrm{PK}=1,7 \%$ (Gambar 11 dan Gambar 12).

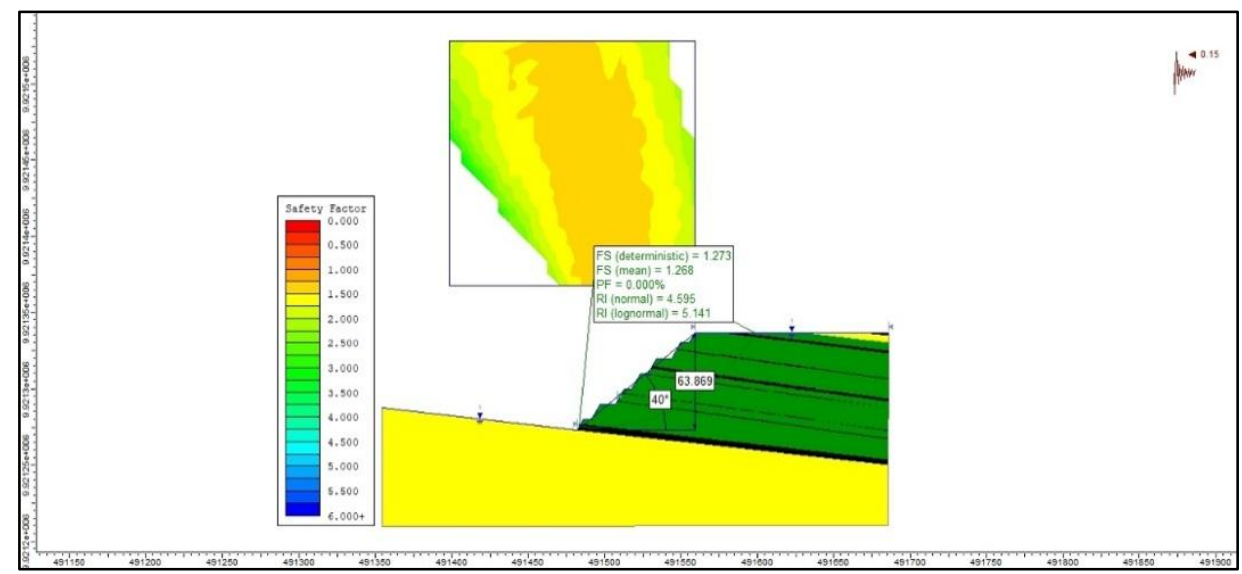

Gambar 11. Simulasi lowwall penampang B-B' (desain awal) $\left(\mathrm{H}=63,869 \mathrm{~m}, \alpha=40^{\circ}, \mathrm{FK}=1,273, \mathrm{PK}=0 \%\right)$

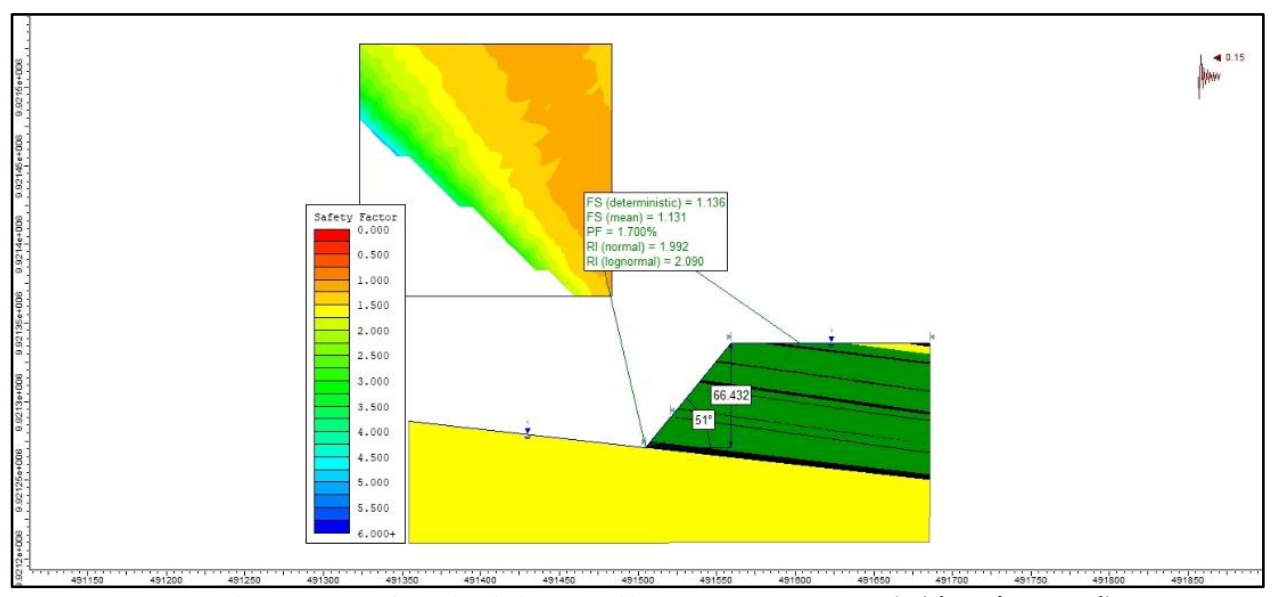

Gambar 12. Simulasi lowwall penampang B-B' (desain awal) $\left(\mathrm{H}=66,432 \mathrm{~m}, \alpha=27^{0}, \mathrm{FK}=1,136, \mathrm{PK}=1,7 \%\right)$

\section{C.3 Pemodelan dan Analisis Kemantapan Lereng Timbunan}

Menurut jenis material yang akan ditimbun, waste dump akan dibentuk oleh timbunan yang terdiri dari atau campuran dua jenis batuan, yaitu batulempung dan batupasir, dengan perbandingan komposisi campuran 55\%: 45\% (data log bor geoteknik).

Analisis kestabilan lereng untuk timbunan (waste dump slope) dilakukan dengan metode keseimbangan batas. Simulasi lereng timbunan menggunakan variasi sudut dan ketinggian lereng yang berbeda-beda untuk menunjukan bahwa semua model yang disimulasikan diharapkan dapat digunakan dalam kondisi yang stabil dengan menggunakan acuan faktor keamanan (FK) 1,20 dan 
memperhitungkan faktor getaran sebesar $0,15 \mathrm{~g}$, contoh simulasi dapat dilihat pada gambar 11 dan rekapitulasi hasil pemodelan dan analasis kemantapan lereng dapat dilihat pada tabel 6 .

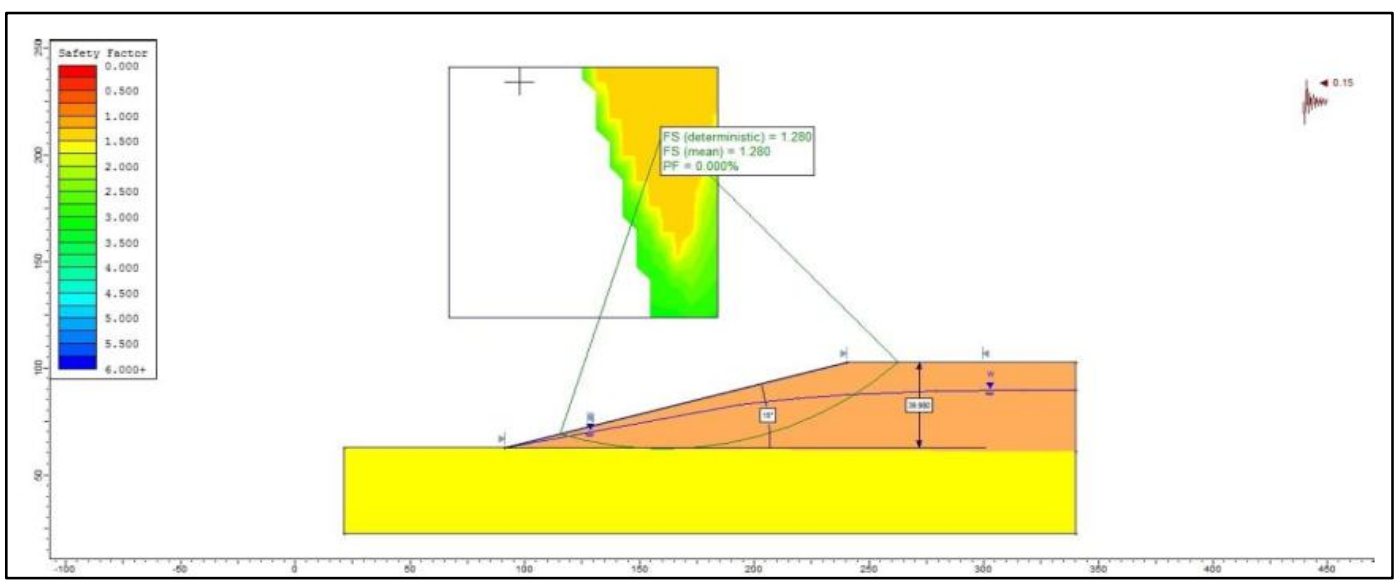

Gambar 13. Simmulasi lereng timbunan di luar pit (OPD) $\left(\mathrm{H}=40 \mathrm{~m}, \alpha=15^{0}, \mathrm{SF}=1,28, \mathrm{PF}=0,00\right)$ 
Tabel 5. Rekapitulasi hasil

\begin{tabular}{|c|c|c|c|c|c|c|c|c|}
\hline PIT & Penampang & Lereng & $\begin{array}{c}\text { Elevasi Terendah } \\
(\mathrm{mdpl})\end{array}$ & $\begin{array}{c}\text { Tinggi } \\
(\mathbf{m})\end{array}$ & $\begin{array}{c}\text { Kemiringan } \\
\left({ }^{\circ}\right) \\
\end{array}$ & SF & PF (\%) & Keterangan \\
\hline \multirow{13}{*}{10} & \multirow{6}{*}{ A-A' } & High-wall & \multirow{3}{*}{-30} & 69,665 & 33 & 1,344 & 0 & Desain Awal \\
\hline & & High-wall & & 76,245 & 48 & 1,209 & 4,9 & Rekomendasi \\
\hline & & Low-wall & & 48,105 & 13 & 1,298 & 0 & Desain Awal \\
\hline & & High-wall 2 & \multirow{3}{*}{-20} & 31,422 & 32 & 1,040 & 14,98 & Desain Awal \\
\hline & & High-wall 2 & & 31,184 & 32 & 1,118 & 0 & Rekomendasi \\
\hline & & Low-wall 2 & & 38,591 & 11 & 1,331 & 0 & Desain Awal \\
\hline & \multirow{4}{*}{ B-B' } & High-wall & \multirow{4}{*}{-15} & 35,892 & 39 & 0,844 & 100 & Desain Awal \\
\hline & & High-wall & & 34,139 & 29 & 1,131 & 0 & Rekomendasi \\
\hline & & Low-wall & & 37,231 & 27 & 1,082 & 0 & Desain Awal \\
\hline & & Low-wall & & 40,109 & 22 & 1,132 & 0 & Rekomendasi \\
\hline & \multirow{2}{*}{$\mathrm{C}-\mathrm{C}^{\prime}$} & High-wall & \multirow{2}{*}{-30} & 97,900 & 30 & 1,137 & 0 & Desain Awal \\
\hline & & Low-wall & & 69,284 & 15 & 1,124 & 1,5 & Desain Awal \\
\hline & $\mathrm{C} 1-\mathrm{C} 1{ }^{\prime}$ & $\begin{array}{l}\text { Low-wall } \\
\text { Gantung }\end{array}$ & -30 & 31,533 & 28 & 1,218 & 0 & Desain Awal \\
\hline \multirow{5}{*}{4 Barat } & \multirow{3}{*}{ D-D' } & High-wall & \multirow{3}{*}{-40} & 73,083 & 36 & 1,321 & 0 & Desain Awal \\
\hline & & High-wall & & 77,023 & 49 & 1,09 & 0 & Rekomendasi \\
\hline & & Low-wall & & 132,165 & 7 & 1,375 & 0 & Desain Awal \\
\hline & \multirow{2}{*}{$\mathrm{O}-\mathrm{O}^{\prime}$} & Side-wall & \multirow{2}{*}{-40} & 63,869 & 40 & 1,273 & 0 & Desain Awal \\
\hline & & Side-wall & & 66,432 & 51 & 1,136 & 1,7 & Rekomendasi \\
\hline \multirow{3}{*}{1} & \multirow{3}{*}{ E-E' } & High-wall & \multirow{3}{*}{-10} & 65,424 & 38 & 1,476 & 0 & Desain Awal \\
\hline & & High-wall & & 66,679 & 43 & 1,100 & 0 & Rekomendasi \\
\hline & & Low-wall & & 89,936 & 7 & 1,406 & 0 & Desain Awal \\
\hline \multirow{12}{*}{7} & \multirow{3}{*}{ F-F' } & High-wall & \multirow{3}{*}{-80} & 141,228 & 29 & 1,022 & 10 & Desain Awal \\
\hline & & High-wall & & 135,305 & 26 & 1,103 & 0 & Rekomendasi \\
\hline & & Low-wall & & 44,401 & 14 & 1,109 & 0 & Desain Awal \\
\hline & $\mathrm{J}-\mathrm{J}^{\prime}$ & High-wall & -50 & 95,000 & 31 & 1,124 & 0 & Desain Awal \\
\hline & & High-wall & & 88,262 & 27 & 1,584 & 0 & Desain Awal \\
\hline & & High-wall & & 89,631 & 34 & 1,223 & 1,7 & Rekomendasi \\
\hline & K-K' & High-wall 2 & -55 & 69,549 & 40 & 1,089 & 10,5 & Desain Awal \\
\hline & & High-wall 2 & & 68,285 & 38 & 1,147 & 2,2 & Rekomendasi \\
\hline & & Low-wall & & 54,463 & 16 & 1,362 & 0 & Desain Awal \\
\hline & $\mathrm{I}_{-} \mathrm{I}^{\prime}$ & Side-wall & 70 & 69,549 & 28 & 1,387 & 0 & Desain Awal \\
\hline & $\mathrm{L}-\mathrm{L}$ & Side-wall & -70 & 68,285 & 34 & 1,133 & 0 & Rekomendasi \\
\hline & M-M' & Low-wall & -55 & 54,463 & 18 & 1,457 & 0 & Desain Awal \\
\hline & & High-wall & & 36,456 & 34 & 2,145 & 0 & Desain Awal \\
\hline & G-G' & High-wall & 0 & 42,868 & 51 & 1,123 & 0,3 & Rekomendasi \\
\hline & & Low-wall & & 45,854 & 19 & 1,348 & 0 & Desain Awal \\
\hline 8 & & High-wall & & 40,000 & 43 & 1,222 & 3,4 & Desain Awal \\
\hline 0 & M-M' & Low-wall & -90 & 115,826 & 19 & 1,021 & 29,1 & Desain Awal \\
\hline & & Low-wall & & 90,000 & 19 & 1,102 & 0,2 & Rekomendasi \\
\hline & N-N' & Side-wall & (00 & 124,703 & 39 & 1,088 & 3,5 & Desain Awal \\
\hline & $1 N-1$ & Side-wall & -90 & 123,182 & 36 & 1,106 & 0,1 & Rekomendasi \\
\hline & G-G' & High-wall & -40 & 80,000 & 41 & 1,145 & 0 & Desain Awal \\
\hline & & Low-wall & -40 & 63,305 & 25 & 1.282 & 0 & Desain Awal \\
\hline 9 & & High-wall & & 30,468 & 41 & 1,544 & 0 & Desain Awal \\
\hline & $\mathrm{I}^{-\mathrm{I}^{\prime}}$ & High-wall & -5 & 30,470 & 49 & 1,245 & 0,3 & Rekomendasi \\
\hline & & Low-wall & & 30,079 & 26 & 1,248 & 0 & Desain Awal \\
\hline & $\mathrm{H}_{-H^{\prime}}$ & High-wall & 30 & 57,973 & 42 & 1,136 & 0 & Desain Awal \\
\hline 11 & $11-11$ & Low-wall & -50 & 51,770 & 25 & 1,289 & 0 & Desain Awal \\
\hline 11 & I-I' & High-wall & -20 & 50,000 & 38 & 1,118 & 0,6 & Desain Awal \\
\hline & $1-1$ & Low-wall & -20 & 44,589 & 24 & 1,364 & 0 & Desain Awal \\
\hline
\end{tabular}


simulasi dan analisis kemantapan lereng pit tambang

Tabel 6. Rekapitulasi hasil pemodelan dan analisis kemantapan lereng timbunan

\begin{tabular}{|c|c|c|c|c|c|c|c|c|c|c|c|c|c|c|}
\hline \multirow{3}{*}{$\begin{array}{l}\text { Tinggi Lereng } \\
\text { Timbunan } \\
\text { (meter) }\end{array}$} & \multicolumn{14}{|c|}{ Sudut kemiringan lereng timbunan (derajat) } \\
\hline & \multicolumn{2}{|c|}{5} & \multicolumn{2}{|c|}{10} & \multicolumn{2}{|c|}{15} & \multicolumn{2}{|c|}{20} & \multicolumn{2}{|c|}{25} & \multicolumn{2}{|r|}{30} & \multicolumn{2}{|r|}{35} \\
\hline & $\mathrm{SF}$ & PF & $\mathrm{SF}$ & PF & SF & $\mathrm{PF}$ & $\mathrm{SF}$ & $\mathrm{PF}$ & $\mathrm{SF}$ & PF & SF & $\mathrm{PF}$ & $\mathrm{SF}$ & $\mathrm{PF}$ \\
\hline 20 & & & & & & & 1,46 & 0,00 & 1,32 & 0,00 & 1,22 & 0,00 & 1,14 & 0,00 \\
\hline 30 & & & & & 1,31 & 0,00 & 1,25 & 0,00 & 1,20 & 0,00 & 1,11 & 0,00 & 0,92 & 100,00 \\
\hline 40 & & & 1,55 & 0,00 & 1,28 & 0,00 & 1,23 & 0,00 & 1,07 & 0,00 & 0,98 & 100,00 & 0,87 & 100,00 \\
\hline 50 & 1,76 & 0,00 & 1,39 & 0,00 & 1,22 & 0,00 & 1,07 & 0,00 & 0,95 & 100,00 & 0,87 & 100,00 & & \\
\hline 60 & 1,46 & 0,00 & 1,25 & 0,00 & 1,02 & 0,00 & 0,90 & 100,00 & 0,80 & 100,00 & 0,70 & 100,00 & & \\
\hline 70 & 1,26 & 0,00 & 1,11 & 0,00 & 0,91 & 100,00 & 0,82 & 100,00 & & & & & & \\
\hline
\end{tabular}

\section{KESIMPULAN}

Perhitungan menggunakan metode kesetimbangan batas secara dua dimensi dapat memberikan pendekatan awal mengenai kondisi stabilitas lereng dengan jenis longsoran busur yang ditunujukan oleh nilai faktor keamanan dan probabilitas kelongsoran. Hasil simulasi dan analisis geoteknik ketika didapati kondisi lereng tidak aman, maka agar lebih mudah dalam redesign geometri lerengnya perlu mengetahui dulu kemantapan lereng tunggal yang nantinya akan diterapkan pada lereng keseluruhan sehingga dapat memiliki acuan nilai geometrinya (tinggi dan sudut kemiringan lereng. Simulasi dan analisis geoteknik yang telah dilakukan pada lereng tunggal, lereng keseluruhan (highwall, sidewall, lowwall) serta lereng timbunan didapati beberapa kesimpulan sebagai berikut :

\section{D.1 Lereng Tunggal}

Hasil simulasi lereng tunggal menggunakan variasi sudut $(50,100,150,200,250,300$, dan 350) dengan ketinggian $(20,30,40,50,60$ dan $70 \mathrm{~m})$. Variasi sudut dan ketinggian yang disimulasikan berada dalam kondisi yang stabil dengan kriteria SF (Stacey, 2009), sehingga dalam merencanakan geometri lereng bukaan tambang dapat menggunakan model mana saja setelah mempertimbangkan faktor produktivitas alat peledakan serta hal lainnya.

\section{D.2 Lereng Keseluruhan}

Simulasi dan analisis untuk lereng keseluruhan yang dilakukan pada beberapa pit menghasilkan kondisi yang aman serta adapula yang tidak aman, berikut adalah hasil simulasi dan analasis desain awal rencana tambang :

- Lereng highwall yang tidak aman terdapat 1 lereng pada pit 10, 2 lereng pada pit 7. Kemudian lereng highwall yang aman terdapat 2 lereng pada pit 10, 1 lereng pada pit 4, 1 lereng pada pit 1,2 lereng pada pit 7,2 lereng pada pit 8,2 lereng pada pit 9, serta 2 lereng pada pit 11.

- Lereng lowwall yang tidak aman terdapat 1 lereng pada pit 10,1 lereng pada pit 8 . Kemudian lereng lowwall yang aman terdapat 3 lereng pada pit 10, 1 lereng pada pit 4, 1 lereng pada pit 1,3 lereng pada pit 7, 1 lereng pada pit 8,2 lereng pada pit 9,2 lereng pada pit 11.

- Lereng sidewall yang tidak aman terdapat 1 lereng pada pit 8. Kemudian lereng sidewall yang aman teradapat 1 lereng pada pit 4 serta 1 lereng pada pit 7 .

Dari hasil simulasi dan analisis geoteknik pada desain awal rencana tambang maka dilakukan desain ulang geometri lereng highwall, lowwall dan sidewall sampai tercapainya lereng keseluruhan yang aman dan optimal. 


\section{D.3 Timbunan}

Hasil simulasi dan analisis kemantapan lereng timbunan di luar pit menggunakan beberapa variasi sudut sudut $\left(55^{\circ}, 60^{\circ}, 65^{\circ}\right.$ dan $\left.70^{\circ}\right)$ dengan ketinggian $(5$ dan $10 \mathrm{~m})$. Dengan menggunakan acuan $\mathrm{SF}>1,20$ dan memperhitungkan faktor getaran sebesar $0,15 \mathrm{~g}$, maka direkomendasikan geometri lereng timbunan di luar pit adalah :

- tinggi $30 \mathrm{~m}$, kemiringan $25^{\circ}$

- $\quad$ tinggi $40 \mathrm{~m}$, kemiringan $20^{\circ}$

- $\quad$ tinggi $50 \mathrm{~m}$, kemiringan $15^{\circ}$

- tinggi $60 \mathrm{~m}$, kemiringan $10^{\circ}$

- tinggi $70 \mathrm{~m}$, kemiringan $5^{\circ}$

\section{E. UCAPAN TERIMA KASIH}

Terimakasih kami ucapkan kepada Bapak Maryanto, atas ide dan sarannya, kemudian kami ucapkan termikasih kepada Bapak Harry yang telah memberikan dukungan kepada kami untuk menulis,serta tak lupa penulis ucapkan terimakasih kepada kawan seperjuangan Ekky S. , Lusitania Hsr, Ridho Qurniawan, Afdal Muhajir dan Arbi Pramuji dalam menyelesaikan tulisan dengan judul "Kajian Geoteknik Untuk Optimalisasi Desain Tambang Batubara Menggunakan Limit Equilibrium Method".

\section{DAFTAR PUSTAKA}

Arif, Irwandy, 2016, Geoteknik Tambang, Gramedia Pustaka Utama, Jakarta.

Astawa Rai, Made. Suseno K.D. dan Ridho K. Wattimena., 2013, Mekanika Batuan, Institut Teknologi Bandung, Bandung.

Bieniawski, Z. T., 1984, Rock Mechanics Design in Mining and Tunneling, A. A. Balkema, Rotterdam.

Bishop, A.W. 1955. The Use the Slip Circle in the Stability Analysis of Slopes. Geotechnique, Vol. 5, No. 1, hal 7-17.

Das, M. Braja, 2006, Principles Of Geotechnical Engineering, Stamford, Cengage Learning

Hoek, E. \& J. W. Bray, 1981. Rock Slope Engineering, Revised Third Edition, The Institution of Mining and Metallurgy, London.

Sulistijo, Budi, 2002, Analisis Kemantapan Lereng Batuan, Kursus Singkat, Geoteknik Terapan Untuk Tambang Terbuka, Departemen Teknik Pertambangan ITB, Bandung. 
PROSIDING TPT XVIII PERHAPI 2019 